\title{
破裂脳動脈瘤極急性期における脳腫脹の検討
}

\author{
篠原 義 賢, 渡辺 義 郎*
}

\section{Acute Brain Swelling on Ruptured Intracranial Aneurysm}

\author{
Yoshikata Shinohara, M.D., and Yoshirou Watanabe, M.D.* \\ Department of Neurosurgery, Kawatetsu Chiba Hospital, and *Department of \\ Neurosurgery, Chiba Emergency Medical Center, Chiba, Japan
}

Summary : The severity of ruptured intracranial aneurysms may be determined by the volume of subarachnoid hemorrhage, the volume of intracerebral hematoma, the presence of intraventricular hemorrhage, or an acute hydrocephalus on the CT scan. But in some cases, brain swelling seemed to be the only determinant factor of severity.

We have experienced 32 such cases among 515 patients with ruptured intracranial aneurysm who were admitted within 72 hours of attack (6.0\%). Five cases had previous convulsions (group 1), and 15 cases had preceding hypoxia and/or hypotension episodes (group 2). But in the remaining 13 cases, we could not find such a preceding episode (group 3).

In group 1, clinical grade on admission varied from $3 \mathrm{~b}$ to 5 , and blood pressure varied from 118/ $80 \mathrm{mmHg}$ to $190 / 100 \mathrm{mmHg}$. Outcomes of this group were one GR, two SD and three death.

Because brain swelling in this group may be a reversible brain edema caused by a convulsion, a delayed operation must be employed.

In group 2, the clinical grade on admission of all patients was five, and blood pressure varied from zero to $210 / 110 \mathrm{mmHg}$. The outcomes of this group were miserable (death: 13, PVS: 1).

Since brain swelling in this group is a manifestation of hypoxic brain damage, there is no indication for an operation.

In group 3, 12 of 13 cases had marked hypertension and the average MABP was $130 \mathrm{mmHg}$. Regional cerebral blood flow measurement by means of Xe inhalation was performed in two cases whose CT scan showed hemispheric swelling, and hyperperfusions of the swelling side were noted. In three cases autopsies were performed, and marked brain swelling, dilated small vessels and diapedesis of erythrocytes were found.

We speculate that acute brain swelling of unknown etiology may be brought about by disautoregulation caused by SAH concomitant with persistent hypertension.

It must be stressed that lowering of blood pressure in the acute phase of a ruptured intracranial aneurysm is very important not only for preventing rebleeding but also for impeding the development of brain swelling.

\section{Key words :}

- acute brain swelling

- subarachnoid hemorrhage

- autoregulation

- hypertensive encephalopathy 


\section{はじめに}

破裂脳動脈瘤急性期の, 重症度を規定する CT スキャン 所見として, クモ膜下出血の量, 脳内出血の量, 脳室内出 血, 水頭症の程度が挙げられている. しかし, 時としてこ れらの所見は軽度であるにもかかわらず，臨床的には重症 であり, 高度の脳腫脹が重症度を規定していると思われる 症例に遭遇する. 破裂脳動脈瘤極急性期にCT スキャンで 認められる, 高度の脳腫脹を引き起こす病態を解析し, 治 療上の問題点を明らかにする。

\section{対象と症例のまとめ}

発症72時間以内に来院した 515 例の破裂脳動脈瘤症例の うち，一側または両側大脳半球の著明な脳腫脹を認めた 32 例 (6.0\%) を対象とした. 脳腫脹を認めるが, 巨大な脳内 血腫や, 硬膜下血腫を有する例は, 除外した.

32 例のうち, 脳動脈瘤破裂直後の痤攣発作を有する群 (第 1 群)は 5 例あり, 無呼吸発作や循環停止などの低酸素 血症を誘因とする群(第 2 群)は，14例であった。また，痤 攣発作や, 低酸素血症などの明らかな誘因の無い群 (第 3 群)は，13例であった.

第 1 群 5 例の, 来院時 grade は, $3 \mathrm{~b} \sim 5$ までに分散し, 予後は, GR 1 例, SD 2 例，死亡 2 例であった. 来院時 血圧は，118/80 mmHg から190/100 mmHg までに分散し た (Table 1).

第 2 群14例の来院時 grade は，すべて 5 であり， 1 例の 植物状態以外すべて死亡した，来院時血圧は，測定不能の 3 例から, 210/110 mmHg まで多彩であった.

第 3 群 13 例の来院時 grade は, Grade III b, Grade IV お のおの 1 例で残り11例は Grade Vであり, 全例死亡した. 来院時血圧は，1例を除き $164 〜 230 / 90 〜 130 \mathrm{mmHg}$ と, 高度の高血圧を呈した。 1 例は前医では190/140 mm Hg であったが，転院する間に，心不全を起こし，来院時は 114/60 mmHg であった.

\section{代 表 症 例}

\section{〔症例 37歳女：Case 3, Table 1, Fig. 1]}

クモ膜下出血発症直後, 㽷攣重積となり他院で Diazepam 静注後, 発症 1 時間で来院した. 来院時 Grade $\mathrm{N}$, 血圧 $118 / 80 \mathrm{mmHg}$ であり, CT スキャンにて軽度のクモ 膜下出血と, 両側大脳半球の腫脹を認めた. 脳血管撮影に て右中大脳動脈瘤を認め, 発症 12 時間で手術を行った。開 頭時, マンニトール $1000 \mathrm{~m} l$ 静注, 過換気, 脳室ドレナー ジを施行するも，脳腫脹は著明であり減圧開頭術のみで手 術を終了した. 術直後の CT スキャンにて, 更なる脳腫脹 を認めたが，第 2 病日には，意識清明となった，第11病日
Table 1 Summary of cases with brain swelling following convulsion

\begin{tabular}{lcclccc}
\hline Case & Age & Sex & $\begin{array}{c}\text { Site of } \\
\text { aneurysm }\end{array}$ & $\begin{array}{c}\text { Grade } \\
\text { on admit. }\end{array}$ & $\begin{array}{c}\text { B.P } \\
\text { ondmit. }\end{array}$ & Outcome \\
\hline 1. & 38 & F & MCA & 5 & $140 / 110$ & D \\
2. & 40 & F & IC & $3 b$ & $164 / 104$ & SD \\
3. & 37 & F & MCA & 4 & $118 / 80$ & GR \\
4. & 51 & M & A-COM & 5 & $190 / 110$ & D \\
5. & 42 & M & IC & 4 & $134 / 96$ & SD \\
\hline
\end{tabular}

に脳腫脹も消失し, neck clipping 施行し, 神経脱落症状 なく退院した.

\section{〔症例〔50歳男：Case 10, Table 2, Fig. 2〕}

突然の意識消失と数十秒の呼吸停止にて発症し, その後 四肢を動かすようになった．救急車中で再び呼吸停止し， CPR 施行しつつ, 第 1 回発作から 1 時間25分, 第 2 回発 作から10分で来院した. 来院時血圧測定不能, GCS 3点で あり，CT スキャンで著明な脳腫脹を認めた。 人工呼吸器, マンニトール使用するも効果なく， 6 時間の経過で脳死に 至った.

\section{〔症例〔47歳女：Case 31, Table 3, Fig. 3, 4]}

突然の頭痛にて発症し 6 時間後に来院し，血圧176/100 $\mathrm{mmHg}, \mathrm{GCS} 13$ 点であった. CT スキャンにて，クモ膜 下出血を認めたが，この時点の脳腫脹は極く軽度であった. 発症12時間後に，右内頸動脈瘤に neck clipping 施行し脳 室脳槽ドレナージを置いた. 術直後 GCS 13点の術前レベ ルに戻ったが，第 1 病日に突然血圧が220/150 mmHg ま で急上昇し，同時に昏睡四肢麻痺 (GCS 3点) となった. CT スキャンにて, 両側大脳半球の高度な脳腫脹を認めた が, 再出血, 梗塞巣は認めず, 脳血管撮影にても, 血管の 狭窄，閉塞は認めなかった。

降圧剂投与により，血圧が $180 / 80 \mathrm{~mm} \mathrm{Hg}$ 程度まで低下 するとともに，意識レベルは改善した。ところが，第 2 病 日にも240/140 mmHg と再び高血圧を呈し, 同時に昏睡 四肢麻痺となった.

CT スキャンにて, 脳腫脹の更なる進行を認め, 直ちに 両側減圧開頭を追加した. その後血圧の下降とともに再び 意識状態は改善したが，第 4 病日に $250 / 140 \mathrm{mmHg}$ とい う著明な高血圧を呈すると同時に昏睡四肢麻痺に至り，人 工呼吸器下にラボナールを使用したが, 第 6 病日に死亡し た(Fig. 3).

剖検所見では, 極めて高度な脳腫脹を認め, 組織学的に は, 細動脈の fibrinoid degeneration や, 血管周囲への赤 血球漏出による点状出血を, 多数認めた (Fig. 4). 


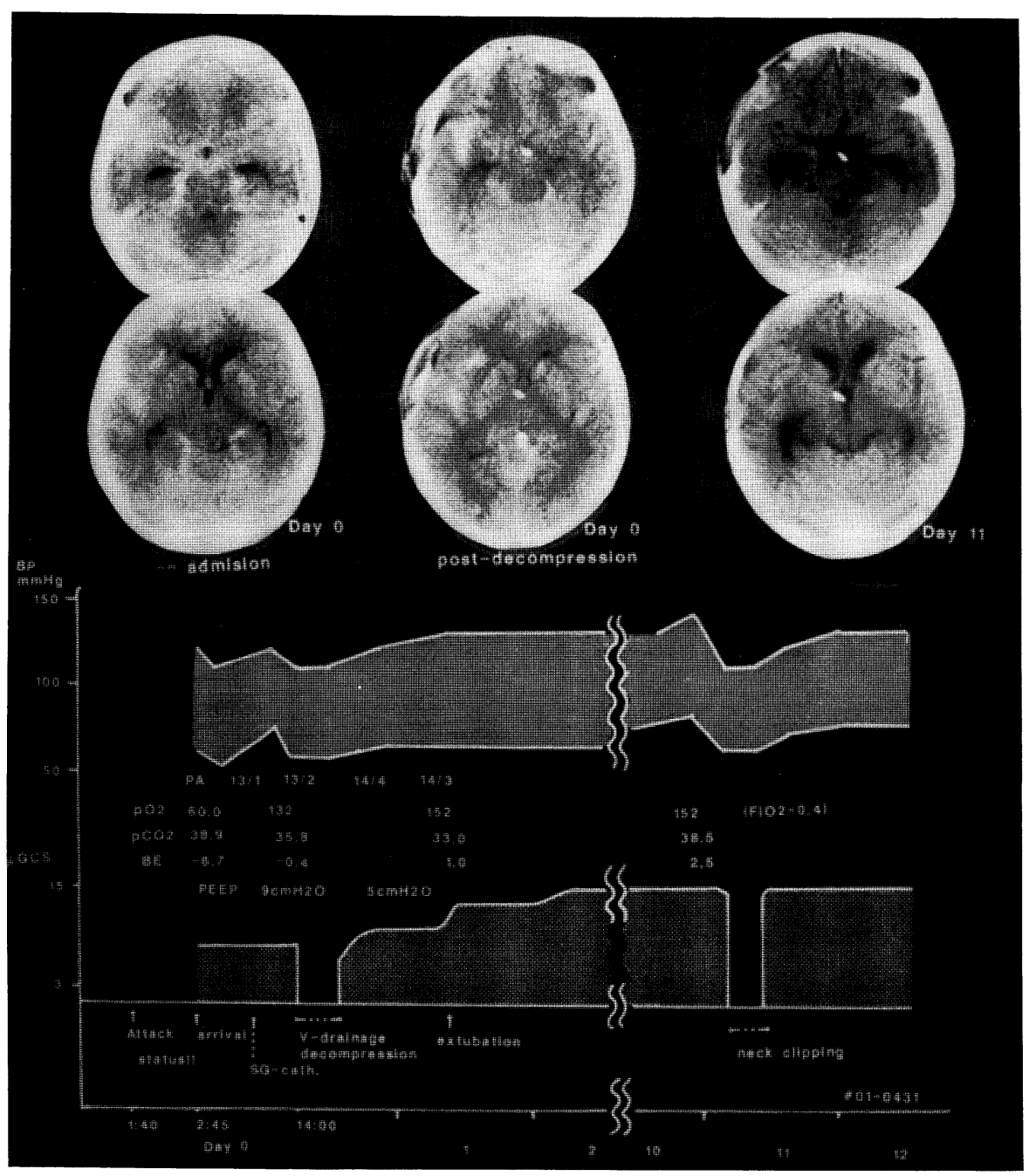

Fig. 1 Clinical summary and CT scans of Case 3. This $37 \mathrm{y} / \mathrm{o}$ female suffered from generalized convulsion just after the SAH attack. Her CT scan on admission showed a small amount of SAH and diffuse brain swelling. Only a ventricular drainage and decompression were performed. Post operative CT scan revealed further brain swelling. On day 11, she had no neurological deficit and CT scan showed improved brain swelling, then neck clipping were performed successfully.

〔症例

48歳女：Case 27 Table 3, Fig. 5]

突然の意識消失にて発症し， 1 時間 30 分後に来院した. 来院時 GCS 5点, 血圧は180/104 mmHgであった. CT ス キャンにて, 右大脳半球に著明な脳腫脹を認めた (Fig. 5 左).

${ }^{133} \mathrm{Xe}$ 吸入法による局所脳血流測定を施行したところ, ISIにて, 腫脹側 $59 \mathrm{~m} l / \mathrm{min}$, 非腫脹側 $23 \mathrm{~m} l / \mathrm{min}$ と, 腫 脹側の hyperperfusion が明らかであった. 強制換気，マ ンニトール使用したが, 発症13時間で脳死に至った。剖検 では，著明な脳腫脹を認め血腫などは認めず，組織学的に は, 細血管の拡張と, 血管周囲への赤血球の漏出を認めた (Fig. 5B).

\section{考察}

実験的疰攣においては脳血管関門が破綻し脳浮腫が生じ るが，痤攣の収束後は脳血管関門は比較的速やかに修復さ れるといわれている1)2).

今回の 515 例のうち動脈瘤破裂直後に痤攣を起こした例 は62例であったが，脳腫脹を呈した例は 5 例のみであった. この 5 例のうち死亡は 2 例のみであり, 臨床的にも, 痤攣 により誘発される脳腫脹は reversible の例も多いことを示 している.病攣自体は破裂脳動脈瘤の予後を悪化させない 3)ため, 症例 3 に示したごとく, 脳腫脹の存在する例に対 しては脳腫脹の軽減を待って根治術を行うべきだと考える. 無呼吸, 循環停止群の脳腫脹は, 低酸素性脳障害を表わ 
Table 2 Summary of cases with brain swelling following apnea and/or circulatory arrest

\begin{tabular}{lcclccc}
\hline Case & Age & Sex & $\begin{array}{c}\text { Site of } \\
\text { aneurysm }\end{array}$ & $\begin{array}{c}\text { Grade } \\
\text { on }\end{array}$ & $\begin{array}{c}\text { B.P.P } \\
\text { odmit. }\end{array}$ & Outcome \\
\hline 6. & 57 & M & B-tip & 5 & DOA & D \\
7. & 49 & M & VA & 5 & $200 / 100$ & D \\
8. & 44 & F & VA & 5 & $102 /$ & D \\
9. & 58 & F & IC & 5 & $200 / 100$ & D \\
10. & 50 & M & B-tip & 5 & DOA & D \\
11. & 48 & F & VA & 5 & $142 / 90$ & D \\
12. & 48 & M & VA & 5 & $84 / 62$ & D \\
13. & 51 & F & IC & 5 & $180 / 100$ & D \\
14. & 42 & M & VA & 5 & DOA & D \\
15. & 50 & M & VA & 5 & $80 /$ & D \\
16. & 65 & F & IC & 5 & $180 / 130$ & V \\
17. & 49 & M & MCA & 5 & $210 / 110$ & D \\
18. & 47 & M & VA & 5 & $210 / 110$ & D \\
19. & 40 & F & VA & 5 & $120 / 80$ & D \\
\hline
\end{tabular}

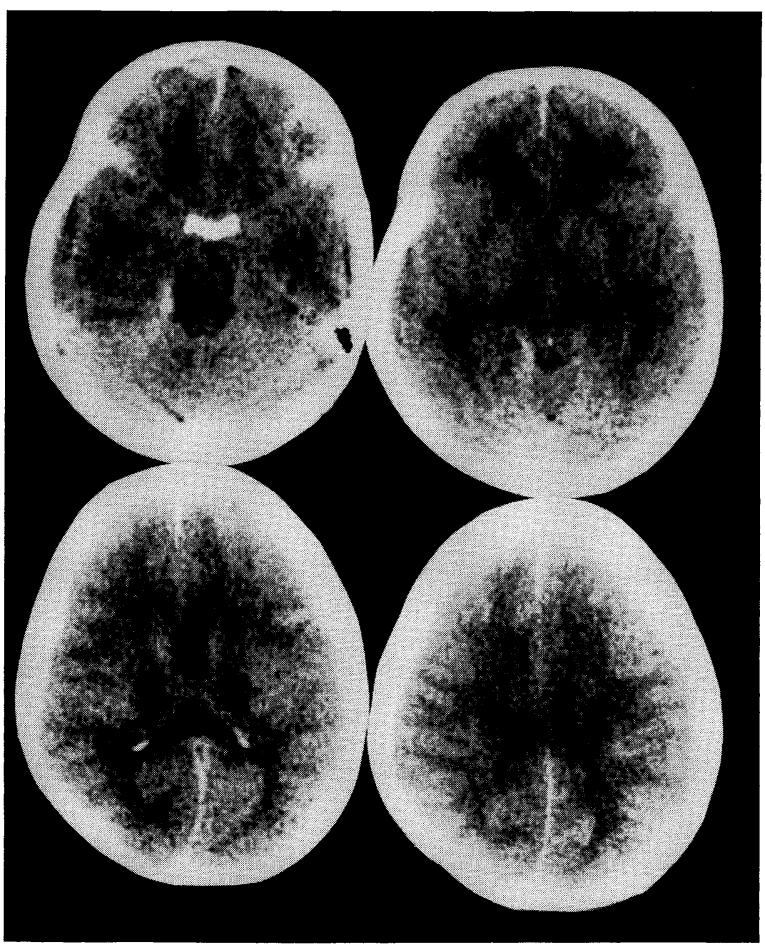

Fig. 2 CT scan of Case 10. This $50 \mathrm{y} / \mathrm{o}$ male had an episode of a sudden LOC and an apnea attack and arrived at the hospital 10 minutes after the second apnea attack. The CT scan on admission showed marked brain swelling. Ventilator support and massive mannitol administration failed to recover him.

しており，予後が絶対的に悪いのは当然である．515例の うち, 無呼吸, 循環停止例は40例あり, そのうち14例に脳 腫脹を認めた。40例全例に低酸素脳障害をきたしていると 思われるが, 脳腫脹例が少ないのは, 血腫・水頭症合併例 や, 循環停止後再循環の起こる以前に死亡した例が含まれ
Table 3 Summary of cases with brain swelling of unknown etiology

\begin{tabular}{lcclcccc}
\hline Case & Age & Sex & $\begin{array}{c}\text { Site of } \\
\text { aneurysm }\end{array}$ & $\begin{array}{c}\text { Grade } \\
\text { on admit. }\end{array}$ & $\begin{array}{c}\text { B.P } \\
\text { on admit. }\end{array}$ & Outcome \\
\hline 20. & 55 & M & A-COM & 5 & $182 / 90$ & D \\
21. & 54 & F & A-COM & 4 & $230 / 110$ & D \\
22. & 61 & F & IC & 5 & $200 / 130$ & D \\
23. & 45 & M & MCA & 5 & $180 / 100$ & D \\
24. & 68 & F & IC & 5 & $* 114 / 60$ & D \\
25. & 44 & F & IC & 5 & $190 / 140$ & D \\
26. & 53 & F & MCA & 5 & $176 / 110$ & D \\
27. & 48 & F & IC & 5 & $180 / 104$ & D \\
28. & 40 & M & IC & 5 & $164 / 90$ & D \\
29. & 53 & F & MCA & 5 & $164 / 100$ & D \\
30. & 57 & M & VA & 5 & $200 / 110$ & D \\
31. & 47 & F & IC & $3 b$ & $176 / 100$ & D \\
32. & 36 & M & MCA & 5 & $190 / 110$ & D \\
\hline
\end{tabular}

* Blood pressure of this case evaluated by the primary doctor was $190 / 140 \mathrm{mmHg}$. This case suffered from heart failure during transfer.

るためと思われる.

臨床的重症度と CT 所見との相関は良く知られているが 4), 破裂脳動脈瘤急性期の全身的な反応は, 無呼吸・循環 停止にまで至らなくても多彩であり ${ }^{3)}$, これらが頭蓋内に 及ぼす悪影響も重大であり，CT スキャンに表現されない 脳障害を十分把握して治療方針を立てることが肝要である.

さて，痤攣や，低酸素血症などの，はっきりした症例の 病態を解明するに当たり, Case 31 は極めて示唆に富む症 例であった。この例は他の例と異なり，来院時 CT スキャ ンでの脳腫脹は極く軽度であったが, 術後, 3 回に亘る過 剩な高血圧発作の度に両側脳腫脹が進行した．剖検所見に て, 著明な脳腫脹と, 細動脈の fibrinoid degeneration, 血管周囲への点状出血を認め, これらの所見は, 高血圧性 脳症の剖検例と同様であった ${ }^{5)}$ 。他の 2 例の剖検例 (Case 21,27)においても, fibrinoid degeneration は認めなかっ たが，著明な脳腫脹と，細血管の拡張，赤血球の漏出を認 めている.

高血圧性脳症は，過㮃な高血圧により，autoregulation の breakthrough が生じ, 細動脈が受動的に拡張し, 脳血 流が増大し，脳血管関門が破綻して急性脳腫脹が発生する といわれている677)8).

我々の13例のうち, 脳血流を測定しえたのは, Case 24,27 の 2 例であった. この 2 症例は, 一側の脳腫脹が著 明であり，腫脹側の脳血流が明らかに非腫脹側より高血流 を呈した。

症例は少ないが，剖検所見と脳血流測定結果から，原因 不明の脳腫脹は，動脈瘤破裂後の全身血圧の上昇が，脳血 管の autoregulation の breakthrough をきたし，細動脈が 


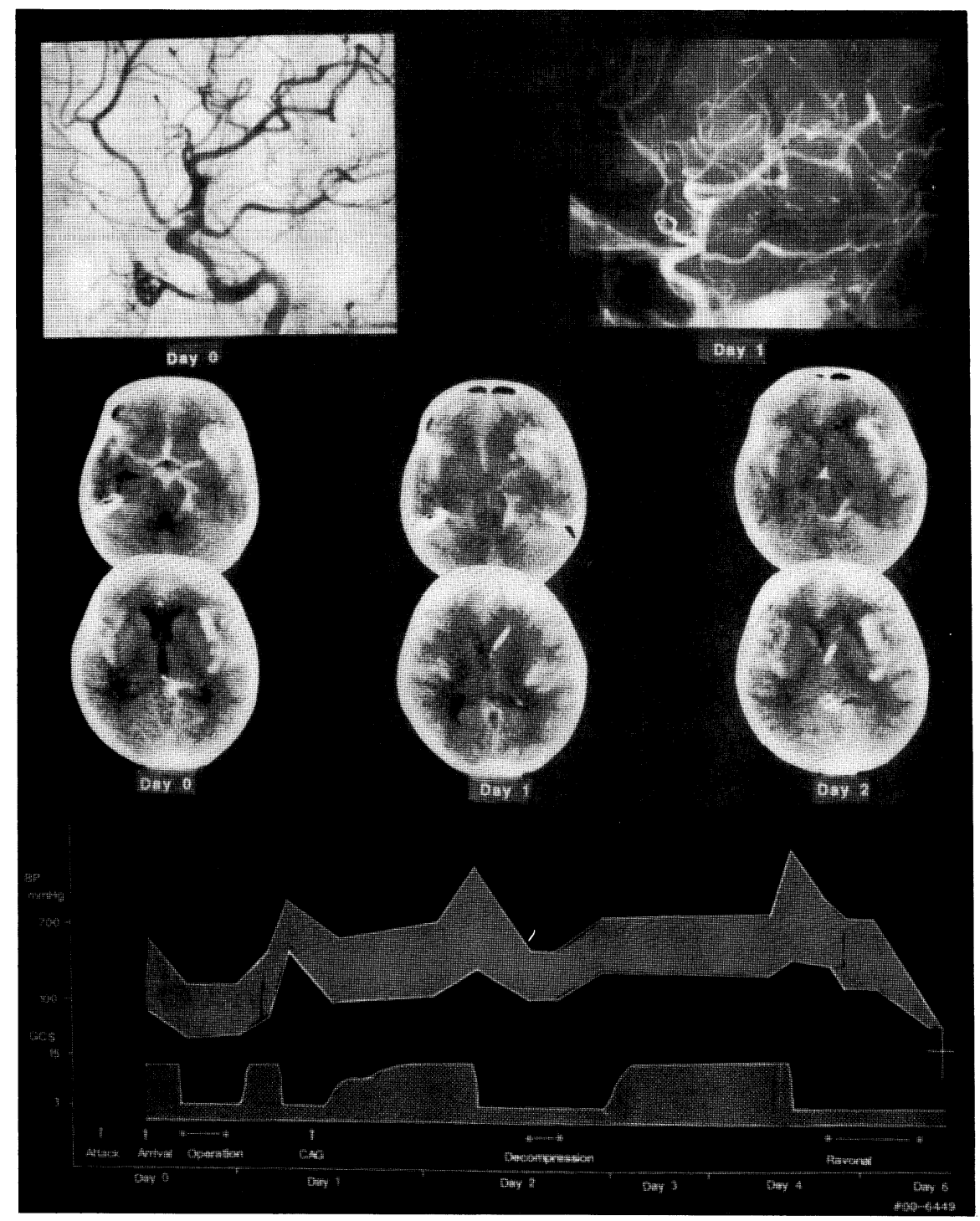

Fig. 3 The clinical summary, angiography and CT scan of Case 31 . This $47 \mathrm{y} / \mathrm{o}$ female arrived at the hospital 6 hours of attack. Her GCS was 13, blood pressure was $176 / 100 \mathrm{mmHg}$ and CT scan showed moderate amount of SAH and minimal brain swelling. Neck clipping of left IC aneurysm and ventricular drainage were performed 12 hours after attack. Though she regained consciousness of the same level as that of preoperation, she experienced extreme hypertension and became deep coma simultaneously on day 1. Although angiography did not reveal any narrowing or occlusion, CT scan showed marked brain swelling. Lowering of blood pressure could made her improve neurological condition. Two other same episode on day 2 and day 4 made her deteriorate, and brain swelling progressed further. Decompressive craniotomy and barbiturate coma could not save her life.

受動的に拡張し脳血流が増大し，脳血管関門が破碇し，赤 血球の漏出も生じることにより引き起こされるものと考え る.

しかし, 通常, autoregulation の breakthrough は, MABP が150〜 $160 \mathrm{mmHg}$ 以上で生ずるとされており ${ }^{9)}$, 我々の症例の来院時 MABP は平均 $130 \mathrm{mmHg}$ であり, breakthrough に至らない例が大部分である. しかし一方, クモ膜下出血においては, 急性期から autoregulation が消 失したり，限界範囲が上下とも狭まっていることが知られ ており ${ }^{10) 〜 13)}$ ，このような条件下では， $130 \mathrm{mmHg}$ 程度の MABP でも, breakthrough が生じると推察される.

クモ膜下出血急性期の脳血流は, 特に重症例では早期か 


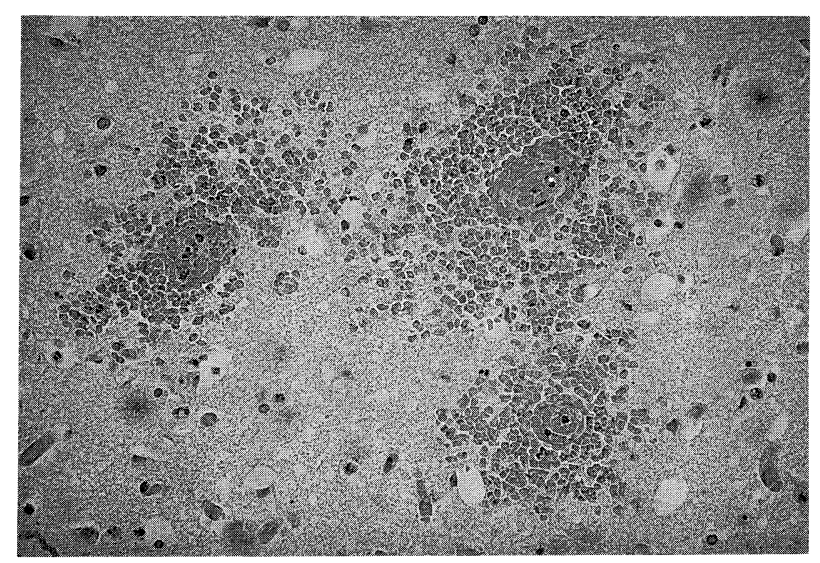

Fig. 4 The photomicrograph of the cerebrum of Case 37. Arteriole with fibrinoid degeneration and diapedesis of red blood cell. Hematoxylin eosin stain.
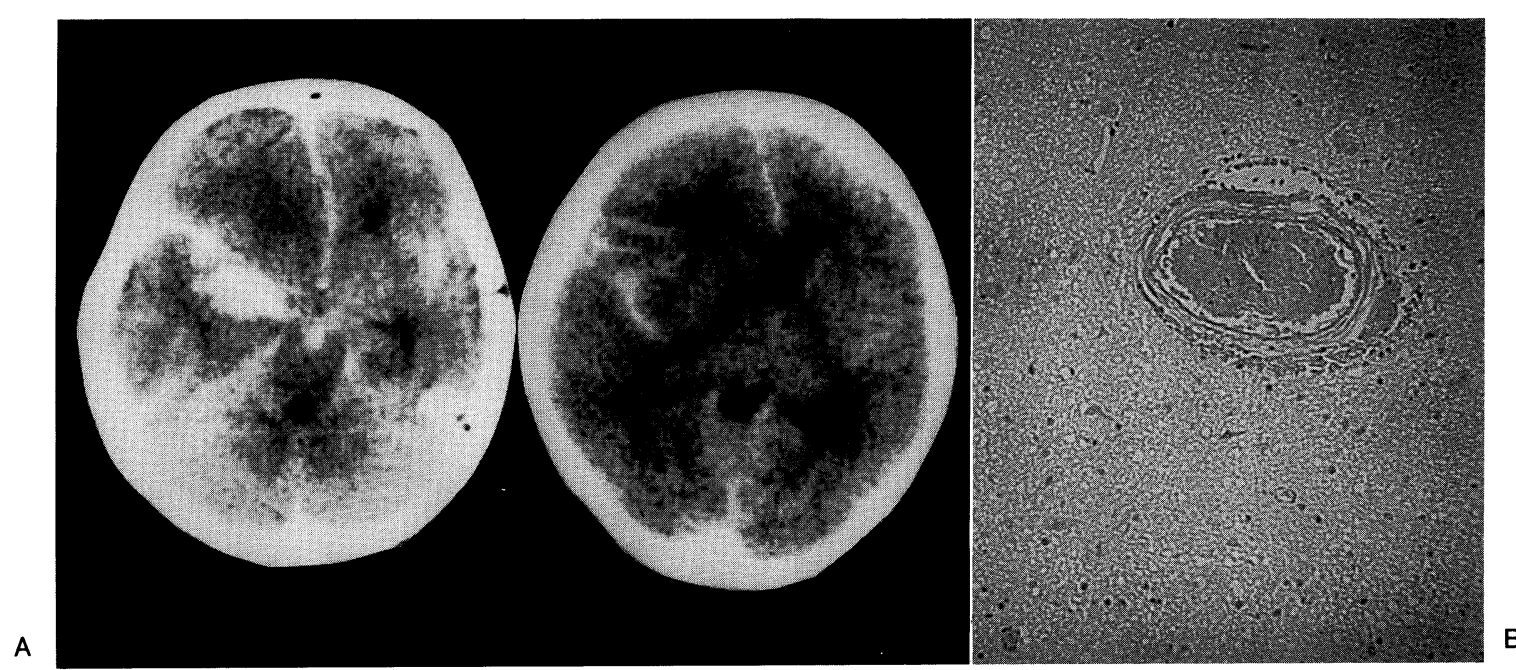

Fig. 5 CT scan (A) and photomicrograph (B) of Case 27. This $48 \mathrm{y} / \mathrm{o}$ female suffered from sudden onset of conscious disturbance, and arrived hospital 1.5 hour of attack. Blood pressure was 180/104 $\mathrm{mmHg}$, and GCS was 5. CT scan showed right hemispheric swelling. Regional cerebral blood flow measured by means of Xe inhalation method. ISI of right hemisphere (swelling side) was 59 $\mathrm{m} l / \mathrm{min}$ and ISI of left hemisphere was $29 \mathrm{~m} l / \mathrm{min}$. Photomicrograph showed dilated small vessels and diapedesis of red blood cells. Hematoxylin eosin stain.

ら低下するという報告が多いが, 臨床例の報告 ${ }^{14) 15) 16) ~}{ }^{16}$ は, 出血直後数時間の測定が無いこと, 実験例 ${ }^{12)}{ }^{17)}$ では, 血圧を正常化する操作が加わっていることから, 我々の症 例のように，発症から数時間の間，過剩な高血圧に露され る極急性期の病態とは, 時間的・条件的に異なる病態を見 ているものと考える.

このように, 破裂脳動脈瘤急性期に, 高血圧が持続する ことは，脳腫脹の進展を引き起こすので，急性期の積極的 な降圧は, 再破裂の予防のみならず, 頭蓋内環境の悪化を 防止する上でも，極めて重要である.

\section{結 論}

1. 515例の急性期破裂脳動脈瘤患者のうち，32例に，両 側または一側半球の脳腫脹を認めた。このうち痤攣発作 に引き続くものは 5 例, 低酸素血症によるものは14例で あった。

2. 原因不明の脳腫脹例は, 来院時高血圧を呈しており, 剖検例において, 細動脈の拡張と赤血球の漏出を認め, 一側半球腫脹例において腫脹側の血流増加を認めた.

3. 原因不明の脳腫脹は, autoregulationの障害に, 遷延 
する高血圧が加わり，通常より低い血圧で autoregulation の breakthrough が起こることにより生ずるものと 考えられた.

\section{文献}

1) Petio CK, Schaefer JA, Plum F: The blood-brain barrier in experimental seizure. In: Dynamics of Brain Edema, Springer-Verlag, 1976, pp 38-42

2) Culter RWP, Lorenzo AV, Barlow CF: Changes in bloodbrain permiability during pharmacologically induced convulsion. Prog Brain Res 29: 367-378, 1968

3）篠原義賢：全身疾患としての破裂脳動脈瘤．第46回日本脳 神経外科学会総会, シンポジウム, 1987

4) 篠原義賢, 渡辺義郎, 中村 弘, ほか: 破裂脳動脈瘤急性 期の臨床的重症度分類と, CT による重症度分類の比較. 第 14回日本脳卒中の外科研究会講演集, 1985

5) Chester EM, Agamanolis DP, Victor M, et al: Hypertensive encephalopathy: A clinicopathologic study of 20 cases. Neurology (Minneap) 28: 928-939, 1978

6) Strangaard S, Olsen J, Lassen NA: Autoregulation of brain circulation in severe arterial hypertention. Br Med J 3: 507-510, 1973

7) Johanson B, Strandgaard S, Lassen NA: On the pathogenesis of hypertensive encephalopathy - The hypertensive "breakthrough" of autoregulation of cerebral blood flow with forced vasodilation, flow increase, and blood-brainbarrier damage. Circ Res 35, 36 (Supple 1): 167-174, 1974

8) MacKenzie ET, Strandgaard S, Harper AM, et al: Effects of acutely induced hypertention in cats on pial arteriolar caliber, local cerebral blood flow and the blood-brain barrier. Circ Res 39: 33-41, 1976

9) Skinhoj E, Strandgaard S: Pathogenesis of hypertensive encephalopathy. Lancet 1: 461-462, 1973

10) Nornes H, Kunutzen HB, Wikeby P: Cerebral arterial blood flow and aneurysm surgery. J Neurosurg 47: 819-827, 1977

11) Pickard JD, Boisvert DPJ, Fitch W, et al: Late effect of subarachnoid hemorrhage on the responce to the primate cerebral circulation to drug induced changes of arterial blood pressure. J Neurol Neurosurg Psychiatry 42: 899903, 1979

12) Jakubowski J, Bell BE, Symon L: A primate model of subarachnoid hemorrhage: Change in regional cerebral blood flow, autoregulation, carbon dioxide reactivity and central conduction time. Stroke 13: 601-611, 1982

13) Boisvert DP, Overton R, Weir B, et al: Cerebral arterial responses to induced hypertension following subarachnoid hemorrhage in the monkey. J Neurosurg 49: 75-83, 1978

14) Ishii R: Regional cerebral blood flow in patients with ruptured intracranial aneurysm. J Neurosurg 59: 587-594, 1979

15) Wier B, Menon D, Overton: Regional blood flow in patients with aneurysms: Estimation by Xenon 133 inhalation. Can J Neurol Sci 5: 301-305, 1978

16）山形 専, 菊池晴彦, 伊藤郁夫, ほか: クモ膜下出血後の 脳循環動態. Neurol Med Chir (Tokyo) 28: 333-339, 1988

17) Kamiya K, Kuyama K, Symon L: An experimental study of the acute stage of subarachnoid hemorrhage. J Neurosurg 59: $917-924,1983$ 